\title{
An Optimized Protocol for Myxosporidia (Cnidaria: Myxosporea) DNA Extraction for Molecular Studies
}

\author{
Guy Benoit Lekeufack-Folefack ${ }^{1}{ }^{*}$, Bienvenu Feudjio-Dongmo', Abraham Fomena ${ }^{1}$, \\ Billy Tene-Fossog', Murielle J. Wondji ${ }^{2,3}$
}

\author{
${ }^{1}$ Department of Animal Biology and Physiology, University of Yaoundé I, Yaoundé, Cameroon \\ ${ }^{2}$ Centre for Research in Infectious Diseases (CRID), Yaoundé, Cameroon \\ ${ }^{3}$ Department of Vector Biology, Liverpool School of Tropical Medicine, University of Liverpool, Liverpool, UK \\ Email: *leguyzo@yahoo.fr, feudonbie91@yahoo.com, abfomena@yahoo.fr, billy.tene@crid-cam.net, \\ murielle.wondji@lstmed.ac.uk
}

\begin{abstract}
How to cite this paper: Lekeufack-Folefack, G.B., Feudjio-Dongmo, B., Fomena, A., Tene-Fossog, B. and Wondji, M.J. (2020) An Optimized Protocol for Myxosporidia (Cnidaria: Myxosporea) DNA Extraction for Molecular Studies. Open Journal of Animal Sciences, 10, 378-386.

https://doi.org/10.4236/ojas.2020.103023
\end{abstract}

Received: April 8, 2020

Accepted: June 8, 2020

Published: June 11, 2020

Copyright $\odot 2020$ by author(s) and Scientific Research Publishing Inc. This work is licensed under the Creative Commons Attribution International License (CC BY 4.0).

http://creativecommons.org/licenses/by/4.0/

\begin{abstract}
Myxosporidia constitute a major group of fish parasites which have a significant negative impact on wild and cultured fish. The used of DNA in Myxosporidia studies has progressed rapidly over the last twenty years, especially in their identification and characterization as well as determination of species diversity and investigation of their evolutionary relationships. Extraction and isolation of pure and high quality DNA are essential for any molecular study, but constitute a challenge for many laboratories especially in low and middle income countries. Myxosporidia plasmodia filled with mature myxospores were isolated from different tissues of Labeo batesii Boulenger, 1911. DNA from myxosporidia myxospores were extracted using a Livak optimized DNAs extraction protocol. Four particular phases of the original protocol were optimized. Yield and absorbance ratios of extracted DNA were determined using spectrophotometer. DNA samples were used as template for the amplification of the $18 \mathrm{~S}$ rDNA region and amplicons resolved on 1.5\% agarose gel for determination of fragment sizes and purity evaluation. The concentration of extracted DNA from all Myxosporidia species ranged from 4.6 to $26 \mathrm{ng} / \mu \mathrm{l}$ with purity indices ranging from 1.88 to 2.12 . We successfully amplified the $1050 \mathrm{bp}$ DNA fragment as targeted. The intensity, thickness and clarity of the bands were evidences of non-degradation of DNA. The optimized Livak protocol is simple, low-cost and manageable. Regarding the quantity, purity and quality of extracted DNA, the optimized Livak protocol is highly recommended for Myxosporidia studies.
\end{abstract}

\section{Keywords}

DNA Extraction, Livak Protocol, Optimization, Myxosporidia, Parasites 


\section{Introduction}

Myxosporidia constitute a group of microscopic metazoan parasites [1], best known for the infections they cause in freshwater and marine fish [2]. To date, about 2400 species of Myxosporidia have been describe worldwide [3] with 280 in Africa [4]. Although their importance as fish parasites is well recognized in Africa, the taxonomy of the majority of Myxosporidia species found on the continent has been based solely on morphological and morphometric characteristics of their myxospores, host and organ or tissue specificity [5].

Approximately 500 DNA sequences originating from Myxosporidia species around the world are deposited in NCBI database with less than 30 from African species [3]. DNA sequence can provide more detailed information not only on the differentiation of myxosporidia species, but also on the diagnosis of economically important species. In addition, the availability of DNA sequences allows a phylogenetic comparison of different species and an investigation of the evolutionary relationships between them [3].

Extraction and isolation of pure and high quality DNA are essential steps for any molecular study [6]. Extensive literature survey clearly indicates that various methodologies have been used to isolate genomic DNA from Myxozoans myxospores [7]-[14]. However, most of these DNA isolation protocols have been reported using commercial kits. Because these commercial kits are very costly, DNA isolation is a challenge for many laboratories in low-incomes countries especially in Africa.

An ideal DNA extraction technique should not only optimize the DNA yield or minimize DNA degradation and contaminant, but it must also be suitable in terms of cost and supplies. Therefore, to extend the molecular and phylogenetic studies of Myxosporidia species to unfunded laboratories in low-incomes countries, it is necessary to establish an efficient and inexpensive DNA extraction protocol for this group of parasites.

Livak [15] has developed a simple, manageable, low cost and efficient protocol for DNA extraction from Drosophila melanogaster Meigen [16]. In the best of our knowledge, no report is available on the use of this method to isolate DNA from myxosporidia.

In the present work, we have optimized the Livak protocol to extract high quality and free of contaminant genomic DNA from Myxosporidia myxospores.

\section{Methods}

\subsection{Sample Collection and Morphological Examination of Myxospores}

Fresh specimens of Labeo batesii Boulenger [17] were sampled in river Makombè at Nkondjock $\left(4^{\circ} 35^{\prime}-5^{\circ} \mathrm{N}, 10^{\circ}-10^{\circ} 23^{\prime} \mathrm{E}\right.$, Cameroon, Central Africa) from May 2017 to July 2018. Captured fish were transported in cool boxes from the field to the Laboratory of Parasitology and Ecology of the University of Yaoundé I. Once in the laboratory, the fish firstly underwent a macroscopic ex- 
amination (eyes, fins, operculum, scales, skin) and a microscopic examination for the presence of Myxosporidia plasmodia using the Olympus BO61 binocular stereoscope. After dissection of a fish specimen, internal organs such as gills, heart, liver, kidneys, spleen, gallbladder, gonads, intestine and urethra were screened for the presence of plasmodia. When found, plasmodia were crushed between glass slides and coverslips, and identified using a light microscope (IVYMEN, objective 100X) according to Lom and Arthur [18]. The remaining myxospores from a ruptured cyst were preserved in $100 \%$ ethanol at $-20^{\circ} \mathrm{C}$ for DNA extraction.

\subsection{DNA Extraction}

This part of the work was carried out at the Centre for Research in Infectious Diseases (CRID), which has a state-of-the-art technical platform for molecular analysis.

The remaining myxospores from each ruptured cyst were separately ground in $25 \mu$ LIVAK grind buffer $(0.08 \mathrm{M} \mathrm{NaCl}, 0.16 \mathrm{M}$ Sucrose, $0.12 \mathrm{M}$ Tris, $0.05 \mathrm{M}$ EDTA, $0.5 \%$ SDS, $100 \mathrm{ml}$ sterilise water) follow by the addition of $75 \mu \mathrm{l}$ of the same buffer to rinse the pestle after grinding. Then, the homogenate was incubated for $30 \mathrm{~min}$ at $65^{\circ} \mathrm{C}$ in a bain-marie. After, a quick spin, $14 \mu \mathrm{l}$ of $8 \mathrm{M}$ $\mathrm{K}$-acetate was added to each tube before incubation on ice for 30 minutes. The mixture was further centrifuged at 13,500 rpm for $20 \mathrm{~min}$. The supernatant was transferred into a new tube and double volume of absolute ethanol was added to it. The samples were centrifuged at $13,500 \mathrm{rpm}$ and kept for incubation at $4^{\circ} \mathrm{C}$ for $15 \mathrm{~min}$ to favour DNA precipitation. The supernatant was then removed and discarded. The DNA pellet was washed with $100 \mu \mathrm{l}$ of cold ethanol $70 \% \mathrm{v} / \mathrm{v}$ and dried at room temperature during 60 minutes. Once dried, the pellet was suspended in $20 \mu \mathrm{l} \mathrm{H}_{2} \mathrm{O}$ and incubates at $65^{\circ} \mathrm{C}$ for $10 \mathrm{~min}$.

\subsection{Quantification and Visualisation of DNA}

DNA concentration and purity were determined using NanoDrop Lite Spectrophotometer (Thermo Fischer scientific). The absorbance quotient (A260/A280) provided an estimation of DNA purity. To verify the quality of the extracted DNA, $3 \mu \mathrm{l}$ of each isolated DNA sample were separated using an agarose gel $1.5 \%$. The gel was stained using midori green (Dutscher/Genetics), visualized and photographed under ultraviolet light.

\subsection{PCR Amplification}

A fragment of $18 \mathrm{~S}$ rDNA was amplified using forward (MC5F:

5'-CCTGAGAAACGGCTACCACATCCA-3') and reverse (MC3R:

5'-GATTAGCCTGACAGATCACTCCACGA-3') primers [19]. Briefly, $1.5 \mu \mathrm{l}$ of extracted DNA were used as template in a mix containing $200 \mathrm{nM}$ of each primer using One Taq Quick-Load (BioLabs inc.) in $15 \mu \mathrm{l}$ of final volume. A Bioer gene touch Thermocycler (Dutscher) was used with a program including an ini- 
tial denaturation step at $95^{\circ} \mathrm{C}$ for 5 minutes, followed by 35 cycles of: a: denaturation at $95^{\circ} \mathrm{C}$ for 60 seconds, annealing temperature at $60^{\circ} \mathrm{C}$ for 60 seconds, and an extension at $72^{\circ} \mathrm{C}$ for 90 seconds. A final extension step at $72^{\circ} \mathrm{C}$ for 5 minutes to terminate the amplification ends the process [20]. The amplified products were visualized on $1.5 \%$ agarose gel.

\section{Results}

\subsection{Plasmodia Content and Morphological Examination of Spores}

Based on morphology and metric features of the Myxospores, three species of Myxobolus were differentiated from three different tissues of Labeo batesii. These Myxobolus species were arbitrarily named Myxobolus sp.1, Myxobolus sp.2 and Myxobolus sp.3. Out of the 454 fishes specimens examined, 138 (30.39\%) harboured plasmodia of Myxobolus sp.1 on the secondary gill lamellae, $81(17.84 \%)$ carried plasmodia of Myxobolus sp.2 on primary gill lamellae while 356 (78.41\%) harboured the plasmodia of Myxobolus sp.3 within the muscle.

\subsection{DNA Yield and Purity}

DNA yield from different Myxobolus species are presented in Table 1 . The concentrations varied between $4.6 \mathrm{ng} / \mu \mathrm{l}$ and $26 \mathrm{ng} / \mu \mathrm{l}$. The absorbance ratio of the extracted DNA measured at wavelengths of $260 / 280 \mathrm{~nm}$ and ranged from 1.88 to 2.12 are presented in Table 1 . Three of the four samples presented an absorbance ratio $<1.8$ whereas one sample has a ratio of $>2.0$.

\subsection{PCR Amplification}

The DNA extracts were successfully used to amplify $18 \mathrm{~S}$ rDNA fragment gene for the three Myxobolus species. The amplified PCR products size of the four DNA samples was of $1050 \mathrm{bp}$ as shown in Figure 1. The amplification procedure was repeated successfully with other extracted samples using the same optimized Livak DNA extraction protocol (unpublished data). As observed in Figure 1, the bands are well defined in 1.5\% agarose gel. The sharpness of these bands showing that there was no sign of degraded DNA during preparation is shown in Figure 1. The amplicons of these 4 isolates samples were used to generate sequence data for the $18 \mathrm{~S}$ rDNA region (unpublished data).

Table 1. Concentration and ratio A260/280 of the DNA samples extracted using Livak modified protocol.

\begin{tabular}{ccc}
\hline Samples & Ratio of absorbance $(260 / 280)$ & DNA yield $(\mathrm{ng} / \mu \mathrm{l})$ \\
\hline 1a & 2.12 & 4.6 \\
1b & 1.97 & 7.8 \\
2 & 1.98 & 8.3 \\
3 & 1.88 & 26 \\
\hline
\end{tabular}

1a \& 1b: Myxobolus sp.1; 2: Myxobolus sp.2; 3: Myxobolus sp.3; ng: nanogram; $\mu$ l: microlitre, DNA: Deoxyribonuleic acid. 


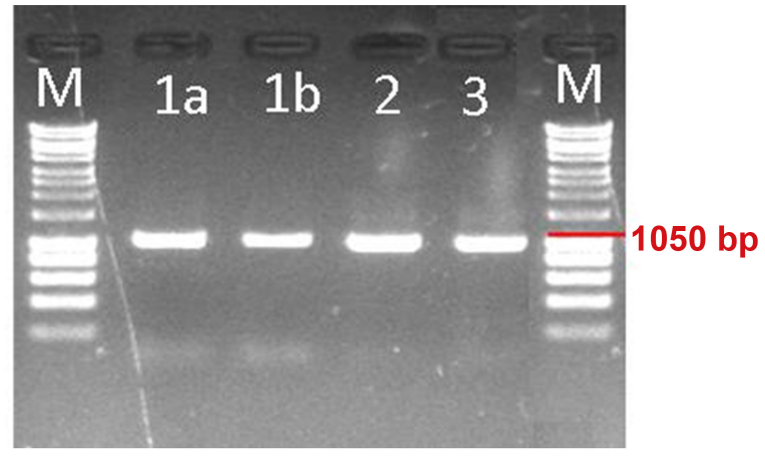

Figure 1. Agarose gel (1.5\%) photo showing amplified 18S rDNA gene of four samples using MC5F/MC3R primers. bp: base pairs; M: size marker; 1a \& 1b: Myxobolus sp.1; 2: Myxobolus sp.2; 3: Myxobolus sp.3.

\section{Discussion}

To date, a wide array of different DNA extraction protocols are in use for Myxosporidia studies. The traditional Phenol-Chloroform method for DNA extraction, have been experience by many authors on Myxosporidia [7] [21] [22]. This extraction method involves the use of lysis STE buffer for suspension of spores before DNA extraction. The preparation of lysis buffer requires proteinase $\mathrm{K}$ which is very expensive. Moreover, proteinase $\mathrm{K}$ in high concentration provides a risk of DNA degradation [23]. Timely availability and expensive price of commercial kits are limiting factors for molecular study in many of the developing countries [6]. The most common commercial kits used in Myxosporidia studies are DNAeasy Blood \& Tissue Kit (Qiagen, USA) [10], QIAamp DNA mini Kit (Qiagen, Germany) [13], Qiagen DNAeasy Tissue Kit (Qiagen) [8], Purelink Genomic Mini Kit (Invitrogen) [12], Fast DNA kit (MP Biomedicals LLC) [9], General All Gen kit [14], TIANamp Genomic DNA kit [11]. A 50 reactions preparation of these commercial DNA extraction kits cost from $\$ 168$ for the cheapest kit (DNAeasy Blood \& Tissue Kit) to $\$ 568$ for the most expensive one (TIANamp Genomic DNA kit). Moreover, they are not easily accessible for purchase and therefore cannot be used by most researchers in underdeveloped countries whose research activities are not always funded.

The present study attempts to propose a less expensive and more accessible method for extracting Myxosporidia DNA. So, the simple and manageable protocol developed by Livak [15] for Drosophila melanogaster DNA extraction was used as starting point and adapted to Myxosporidia. The reagents components of the Livak buffer that cost less than $\$ 10$ for a 50 reactions preparation are easily accessible and always available. The formulation of the Livak buffer can easily be modified contrary to those of the commercial kits. Four particular phases in the Livak protocol were optimized:

- the buffer was prepared in accordance with the original procedure but to avoid any DNA loss, the buffer $(100 \mu \mathrm{l})$ was added in two phases: firstly (25 $\mu \mathrm{l})$ to grind the plasmodia and secondly $(75 \mu \mathrm{l})$ to rinse the pestle after grinding; 
- to avoid any dislodging of the DNA pellet, the pellet was washed only one time using $100 \mu \mathrm{l}$ of cold $70 \%$ ethanol instead of two times;

- the DNA pellet was suspended in $20 \mu \mathrm{H}_{2} \mathrm{O}$ instead of $40 \mu \mathrm{l}$ of restriction enzyme buffer proposed by Livak [15]. Use of water in this step is vital for further molecular techniques such as PCR application, RFLP and sequencing [24] [25];

- the final incubation at $65^{\circ} \mathrm{C}$ for $10 \mathrm{~min}$ (step lacking in Livak [15] protocol) allowed the total dissolution of DNA pellet and the destruction of any DNases that may be present [26].

When spooled out of solution, the DNA shows on agarose gel some white, thick and intact bands with no visible coloration. Furthermore, The $\mathrm{A}_{260 / 280}$ ratio of the DNA from three out of the four Myxosporidia samples used ranged from 1.88 to 1.98 indicating that the isolated DNA is free from protein and RNA contamination [27] [28] and could be used for further molecular and bioinformatics investigations.

\section{Conclusion}

The present study provides the first report on the use of an optimized Livak protocol for Myxosporidian DNA extraction. The method is simple, manageable, low cost and efficient for genomic DNA isolation from Myxosporidia myxospores. The amount, purity and quality of the DNA extracted are suitable for molecular studies. This optimized Livak protocol, highly recommended for molecular studies of Myxosporidia, can also be extended for DNA extraction of other fish parasites as well in many laboratories especially in low and middle income countries.

\section{Acknowledgements}

We appreciate Professor Charles Wondji and his research team for the assistance rendered during laboratory analysis.

\section{Authors' Contribution}

L. F. G. B., F. D. B. and T. F. B. drafted the proposal, L. F. G. B., F. D. B. and W. M. J. participated in the field work and laboratory analysis, L. F. G. B., F. D. B. and T. F. B. participated in the data analysis and interpretation, F. A. and W. M. J. contributed to the correction of the final draft of the manuscript. All authors read, corrected and approved the final manuscript.

\section{Conflicts of Interest}

The authors declare no conflicts of interest regarding the publication of this paper.

\section{References}

[1] Pote, L.M., Hanson, L.A. and Shivaji, R. (2000) Small Subunit Ribosomal RNA Se- 
quences Link the Cause of Proliferative Gill Disease in Channel Catfish to Henneguya n. sp. (Myxozoa: Myxosporea). Journal of Aquatic Animal Health, 12, 230-240.

[2] Lom J. and Dyková I. (2006) Myxozoan Genera: Definition and Notes on Taxonomy, Life-Cycle Terminology and Pathogenic Species. Folia parasitologica, 53, 1-36. https://doi.org/10.14411/fp.2006.001

[3] Fiala, I., Bartošová-Sojková, P. and Whipps, C.M. (2015) Classification and Phylogenetics of Myxozoa. In: Okamura, B., Gruhl, A. and Bartholomew, J.L., Eds., Myxozoan Evolution, Ecology and Development, Springer International Publishing AG, Switzerland, 85-110.

[4] Deli, A., Lekeufack Folefack, G.B. and Fomena, A. (2017) Description of Myxidium tetraodoni sp. nov., Myxidium anisocapsularis sp. Nov. and Myxobolus magai sp. nov. (Myxosporea: Bivalvulida) Infecting Some Freshwater Fishes in Cameroon (Central Africa). Fisheries and Aquaculture Journal, 8, 1-10. https://doi:10.4172/2150-3508.1000235

[5] Lekeufack Folefack, G.B., Abdel-Baki, A.A.S., Ateba, N.O.O., Fomena, A. and Mansour, L. (2019) Morphological and Molecular Characterization of Myxobolus dibombensis sp. n. (Myxozoa: Myxobolidae), a Parasite of the African Carp Labeobarbus batesii (Teleostei: Cyprinidae) from Dibombe River, Cameroon. Parasitology Research, 118, 763-771. https://doi.org/10.1007/s00436-019-06209-w

[6] Júnior, C.D.S., Teles, N.M.M., Luiz, D.P. and Isabel, T.F. (2016) DNA Extraction from Seeds. In: Sample Preparation Techniques for Soil, Plant, and Animal Samples, Humana Press, New York, 265-276.

[7] Eszterbauer, E., Benkó, M., Dán, Á. and Molnár, K. (2001) Identification of Fish-Parasitic Myxobolus (Myxosporea) Species Using a Combined PCR-RFLP Method. Diseases of Aquatic Organisms, 44, 35-39. https://doi.org/10.3354/dao044035

[8] Molnar, K., Cech, G. and Szekely, C. (2008) Myxobolus Species Infecting the Cartilaginous Rays of the Gill Filaments in Cyprinid Fishes. Acta Parasitologica, 53, 330-338. https://doi.org/10.2478/s11686-008-0054-3

[9] Mansour, L., Harrath, A.H., Abd-Elkader, O.H., Alwasel, S., Abdel-Baki, A.A.S. and Al Omar, S.Y. (2014) Structural and Molecular Characterization of Kudoa quraishii n. sp. from the Trunk Muscle of the Indian Mackerel Rastrelliger kanagurta (Perciforme, Scombridae) in Saudi Arabia Coasts. Parasitology Research, 113, 1361-1370. https://doi.org/10.1007/s00436-014-3775-2

[10] Mansour, L., Abdel-Baki, A.A.S., Al-Qahtani, H.A. and Al-Quraishy, S. (2015) Morphological and Molecular Aspects of Ceratomyxa mehlhorni n. sp., a Parasite of the Golden Trevally Gnathanodon Speciosus in the Arabian Gulf off the Saudi Arabian Coast, with Data on Its Seasonal Prevalence. Parasitology Research, 114, 3783-3789. https://doi.org/10.1007/s00436-015-4608-7

[11] Guo, Q., Zhai, Y., Gu, Z. and Liu, Y. (2016) Histopathological and Ultrastructural Studies of Myxobolus turpisrotundus from Allogynogenetic Gibel Carp Carassius auratus gibelio in China. Folia Parasitologica, 63, 1.

https://doi.org/10.14411/fp.2016.033

[12] Abrunhosa, J., Sindeaux-Neto, J.L., Santos, Â.K.D., Hamoy, I. and Matos, E. (2017) Myxobolus marajoensis sp. n. (Myxosporea: Myxobolidae), parasita do bagre de água doce Rhamdia quelen da região da Amazônia brasileira. Revista Brasileira de Parasitologia Veterinária, 26, 465-471. https://doi.org/10.1590/s1984-29612017067

[13] Abdel-Baki, A.A.S., Abdel-Haleem, H.M., Al-Quraishy, S., Azevedo, C. and Man- 
sour, L. (2018) Ultrastructural and Molecular Characteristics of Kudoa crenimugilis n. sp. Infecting Intestinal Smooth Muscle of Fringelip Mullet Crenimugil crenilabis in the Red Sea. Diseases of Aquatic Organisms, 129, 53-62.

https://doi.org/10.3354/dao03225

[14] Zhang, X., Liu, Y., Whipps, C.M., Guo, Q. and Gu, Z. (2019) Multiple Evolutionary Routes of the Single Polar Capsule in Thelohanellus Species (Myxozoa; Myxobolidae). International Journal for Parasitology: Parasites and Wildlife, 8, 56-62. https://doi.org/10.1016/j.ijppaw.2018.11.006

[15] Livak, K. (1984) Organization and Mapping of a Sequence on the Drosophila melanogaster $\mathrm{X}$ and $\mathrm{Y}$ Chromosomes that Is Transcribed during Spermatogenesis. Genetics, 107, 611-634.

[16] Meigen, J.W. (1830) Systematische Beschreibung der bekannten europäischen zweiflügeligen Insekten. 6. Schulz-Wundermann, Hamm, Germany.

[17] Boulenger, G.A. (1901) On the Fishes Collected by Dr. WJ Ansorge in the Niger Delta. Proceedings of the Zoological Society of London, 1, 4-10.

[18] Lom, J. and Arthur, J.R. (1989) A Guideline for the Preparation of Species Descriptions in Myxosporea. Journal of Fish Diseases, 12, 151-156. https://doi.org/10.1111/j.1365-2761.1989.tb00287.x

[19] Molnár, K., Eszterbauer, E., Székely, C., Dán, Á. and Harrach, B. (2002) Morphological and Molecular Biological Studies on Intramuscular Myxobolus spp. of Cyprinid Fish. Journal of Fish Diseases, 25, 643-652. https://doi.org/10.1046/j.1365-2761.2002.00409.x

[20] Adriano, E.A., Carriero, M.M., Maia, A.A.M., Silva, M.R.M.D., Naldoni, J., Ceccarelli, P.S. and Arana, S. (2012) Phylogenetic and Host-Parasite Relationship Analysis of Henneguya multiplasmodialis n. sp. Infecting Pseudoplatystoma spp. in Brazilian Pantanal Wetland. Veterinary Parasitology, 185, 110-120. https://doi.org/10.1016/j.vetpar.2011.10.008

[21] Liu, Y., Whipps, C.M., Gu, Z.M., Huang, M.J., He, C., Yang, H.L. and Molnár, K. (2013) Myxobolus musseliusae (Myxozoa: Myxobolidae) from the Gills of Common Carp Cyprinus carpio and Revision of Myxobolus dispar Recorded in China. Parasitology Research, 112, 289-296. https://doi.org/10.1007/s00436-012-3136-y

[22] Huang, M., Liu, Y., Jia, L., Zhai, Y., Deng, Q. and Gu, Z. (2014) Supplementary Studies on Myxobolus tsangwuensis Chen, 1954 (Myxozoa: Myxosporea) Infecting the Gills of Common Carp Cyprinus carpio (L.): Molecular and Histological Data. Acta Parasitologica, 59, 653-660. https://doi.org/10.2478/s11686-014-0292-5

[23] Da Silva, L.E., Dos Santos Silva, D.B., Do Amaral Crispim, B., Vaini, J.O., Grisolia, A.B. and De Oliveira Seno, L. (2013) Variação de concentração de proteinase K em protocolos de extração de DNA de bovino. Archives of Veterinary Science, 18, 15-19. http://dx.doi.org/10.5380/avs.v18i2.26151

[24] Gomes, L.H., Duarte, K.M.R., Andrino, F.G. and Tavares, F.C.A. (2000) A Simple Method for DNA Isolation from Xanthomonas spp. Scientia Agricola, 57, 553-555. https://doi.org/10.1590/S0103-90162000000300028

[25] Gaikwad, A.B. (2002) DNA Extraction: Comparison of Methodologies. PLoS Biology, 20, 162-173.

[26] Allen, G.C., Flores-Vergara, M.A., Krasynanski, S., Kumar, S. and Thompson, W.F. (2006) A Modified Protocol for Rapid DNA Isolation from Plant Tissues Using Cetyltrimethylammonium Bromide. Nature Protocols, 1, 2320.

https://doi.org/10.1038/nprot.2006.384 
[27] Sambrook, J. and Russell, D.W. (2001) Molecular Cloning. A Laboratory Manual. Cold Spring Harbor Laboratory Press, New York.

[28] Desjardins, P. and Conklin, D. (2010) NanoDrop Microvolume Quantitation of Nucleic Acids. Journal of Visualized Experiments, 45, 2565. https://doi.org/10.3791/2565 